\title{
Transplantation to Localisation: The Importation of Western Structural Technologies in Modern Shanghai Architecture Based on a Study of the Bund Buildings, 1843-1943
}

\author{
Peng Zhang* and Yijiao Yang \\ College of Architecture and Urban Planning, Tongji University, Shanghai, China \\ Corresponding author: zhangpeng_patrick@tongji.edu.cn
}

\begin{abstract}
Shanghai's modern architectural heritage in the $19^{\text {th }}$ and early $20^{\text {th }}$ centuries is an essential aspect of modern Chinese architectural history because of its outstanding characteristics and well-preserved conditions. Modern Shanghai architecture was transformed by the importation of Western structural technologies and materials in addition to their forms and institutions. After 100 years of development since 1843, there were over 100 important buildings in the Bund area by 1943. These buildings were built in different periods using the best available structural technologies. This study focuses on the technological dimension of modern Shanghai architecture. Based on an architectural survey and a literature investigation of the Bund buildings, this study explores the evolution of modern structural technologies in Shanghai by analysing the Bund buildings' key structural factors. The influences of the localisation and implementation of Western architecture's building technologies in Shanghai were also analysed, including time of importation, characteristics and integration of local craftsmanship and materials. This study focuses on the method and analyses of architectural technology history from not only technological and historical perspectives, but also a social sciences perspective.
\end{abstract}

KEYWORDS Western structural technologies, transplantation, localisation, Shanghai, Bund Buildings

Received March 10, 2019; accepted March 14, 2019.

\section{Background}

Since the mid- $19^{\text {th }}$ century, the modernisation of Chinese cities and architectural styles has proceeded gradually based on the importation of Western experiences and technologies, such as urban infrastructure, building structures, materials and architectural equipment. The localisation of Western building technologies led to a comprehensive modern transformation of the cultural dimensions of Chinese cities, from architectural styles and construction management to social customs. Thus, the influences of modernisation spread all over the country from the past to the present. Some scholars have summarised this process as 'the gradual development and interaction of technologies, institutions and ideas' (Li 2004, 342). Thus, this process of transformation began with the import and spread of new building technologies, which led to new social divisions of labour, related industries and practical mechanisms. Finally, this process led to variations and innovations in Chinese architectural systems and the transformation of ideas. Therefore, there can be no doubt that the introduction of Western building technologies is one of the most fundamental factors in this evolutionary process.

Shanghai's role in the process of modernising China is unique. In the $19^{\text {th }}$ century, the British colonialists strategically sited their settlement at the intersection of the Huangpu River and Soochow Creek based on their distinct vision of its defensive characteristics. Shanghai quickly became the biggest city in the Far East because of its natural conditions, such as its location and weather, and its special politico-economic characteristics. Shanghai also became the most important port in China because of its importation of Western technologies and culture. Western architectural technology first came to Shanghai and was then swiftly localised so that it could be spread across China. 


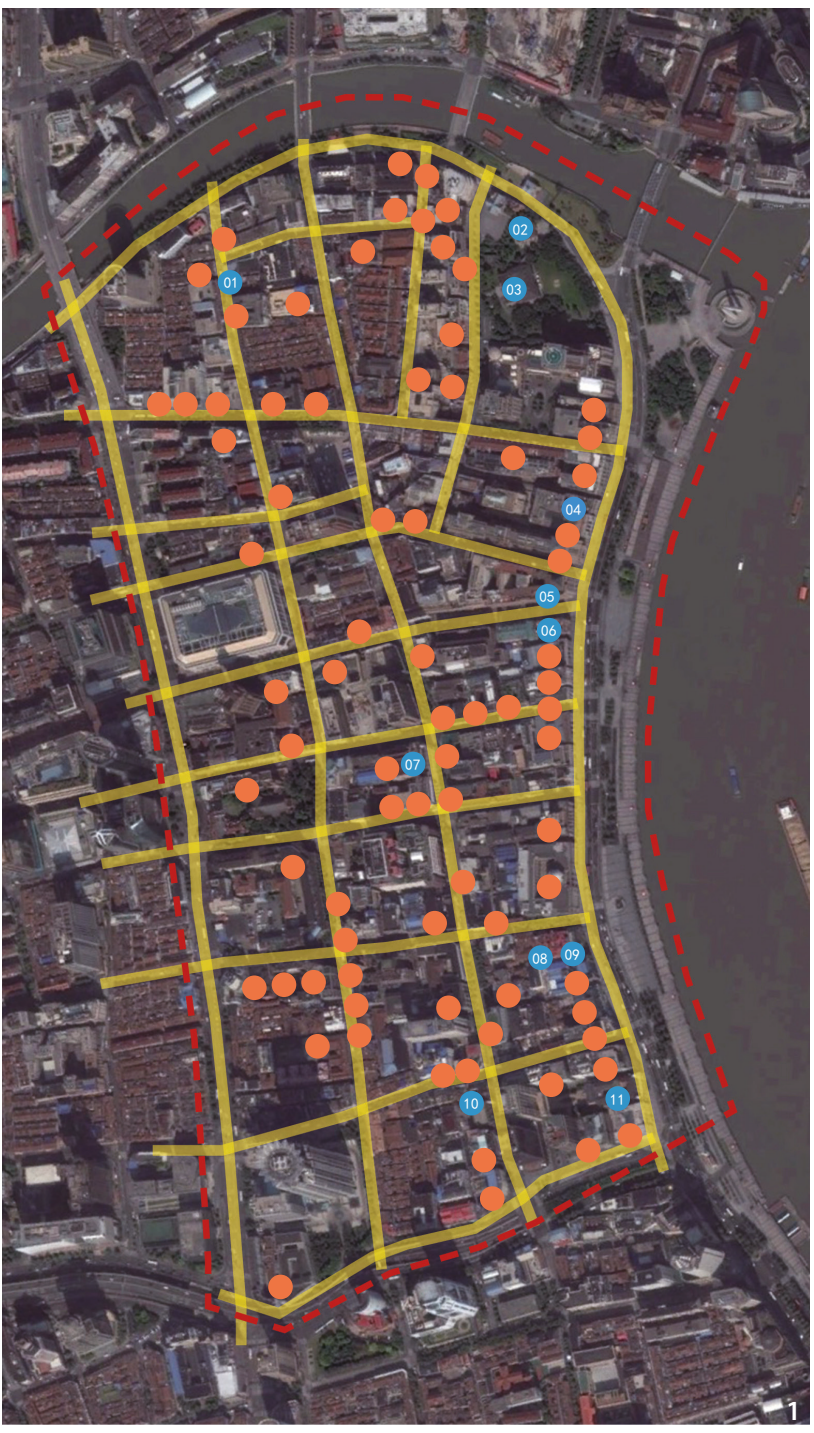

1. The British Merchant Water Company Building (No. 464-466 Middle Jiangxi Road)

2. The former Residence of British Consulate General (No. 33 East Zhongshan Road)

3. The British Consulate General (No. 33 East Zhongshan Road)

4. The Yangtze Insurance Building (No. 26 East Zhongshan Road)

5. The former Sassoon House (No. 20 East Zhongshan Road)

6. The former Palace Hotel (No. 19 East Zhongshan Road)

7. The Bank of East Asia Building (No. 299 Middle Sichuan Road)

8. The North Bandinel \& Co. Building (No. 17-19 Fuzhou Road)

9. The China Merchants Steam Navigation Company Building (No. 9 East Zhongshan Road)

10. The China Mutual Life Insurance Co. Building (No. 93 Guangdong Road)

11. The former Shanghai Club (No. 2 East Zhongshan Road)

Figure 1 The Bund area of Shanghai and the location of the studied buildings. The blue dots showed the buildings which were discussed in the paper. (Source: the author).

The localisation of Western structural technologies in modern Shanghai architecture is one of the most significant aspects in the localisation of Western building technologies. To ensure that this structural analysis fully reflects the different periods since Shanghai opened up its port to the world, the earliest British Settlement as set out in the 1845 Shanghai Land Regulations was chosen as the study area; i.e., the area to the east of Middle Henan Road, to the north of East Yan'an Road, to the west of Huangpu River and to the south of Suzhou River. 89 heritage buildings were studied in this area, which was one of modern Shanghai's earliest areas of construction. During the 100 years' history of the Settlement in Shanghai, the area's architecture embodies the styles and structural features of different periods and mostly embodies the highest achievements of modern Chinese architecture (Figure 1).

\section{The Structural Evolution of Modern Shanghai Buildings}

From the $17^{\text {th }}$ to the $19^{\text {th }}$ centuries, great progress and changes were made in European construction technologies. In 1678, Hooke's law on the elastic characteristics of materials was published, while the first monograph on the strength of materials appeared in 1751 and the buckling problem of columns was solved in 1757. Cast and forged iron were simultaneously widely used in Britain since the $18^{\text {th }}$ century. Forged iron was the first durable tensile material; it was easy to process and showed very consistent elastic characteristics with Hooke's law, which made structural calculations possible. During the same period when new structural practices were in full swing in Britain, France also developed a complete structural theory. École des Ponts Paris Tech, one of the oldest institutions in the field of science, engineering, and technology worldwide, was established and quickly became a research centre for structural mechanics. Thus, Western architectural technologies were also undergoing rapid changes while they simultaneously opened a gateway to the Far East.

Before Shanghai opened as a treaty port in 1843 , its buildings still used a traditional Chinese timber structure. The typical characteristics of traditional Chinese timber structures include load-bearing timber pillars, brick walls, and roof support using lifting beams or a mortise-and-tenon structure. This mortise-and-tenon structure was mainly applied to vernacular dwellings in south China. After Shanghai opened its port to world trade and foreign settlements were established, these foreigners also imported their Western architectural cultures and influences into Shanghai. However, no professional architect or builder was among these foreigners; therefore, their buildings were mostly a combination of colonial styles using local materials and construction techniques. This was the beginning of the localisation of Western architectural styles in Shanghai. From the establishment of the British Settlement in 1843 to the end of the foreign settlement system in 1943, modern Shanghai architectural structures can be roughly separated into three phases: 
Table 1 Main information of different structure types (Source: the author).

\begin{tabular}{|c|c|c|c|c|c|c|c|}
\hline Structure type & $\begin{array}{l}\text { Time of } \\
\text { import }\end{array}$ & $\begin{array}{l}\text { Year lag } \\
\text { between West } \\
\text { and Shanghai }\end{array}$ & $\begin{array}{c}\text { Main vertical } \\
\text { material }\end{array}$ & $\begin{array}{c}\text { Main horizontal } \\
\text { material }\end{array}$ & $\begin{array}{l}\text { Mixed } \\
\text { system }\end{array}$ & $\begin{array}{l}\text { Structural } \\
\text { calculation }\end{array}$ & $\begin{array}{l}\text { Building- } \\
\text { Codes } \\
\text { regulated }\end{array}$ \\
\hline Masonry-timber & 1843 & - & Brick, stone & Timber & Yes & No & Partly \\
\hline $\begin{array}{l}\text { Masonry reinforced- } \\
\text { concrete }\end{array}$ & $\begin{array}{l}\text { End of } 19^{\text {th }} \\
\text { century }\end{array}$ & 11 & Brick, stone & Reinforced-concrete & Yes & Partly & Yes \\
\hline $\begin{array}{l}\text { Reinforced-concrete } \\
\text { frame and steel frame }\end{array}$ & $\begin{array}{l}\text { Dawn of } 20^{\text {th }} \\
\text { century }\end{array}$ & 5 & $\begin{array}{l}\text { Reinforced-con- } \\
\text { crete, steel }\end{array}$ & $\begin{array}{l}\text { Reinforced-con- } \\
\text { crete, steel }\end{array}$ & No & Yes & Yes \\
\hline
\end{tabular}

i.e., a masonry-timber structure phase, a masonry-steelreinforced concrete structure phase and a frame structure with reinforced concrete or steel phase (Table 1). During each phase, the new types of structures emerged and became popular while the earlier architectural styles were still in use.

\section{Phase 1: Old Hybrid Structure: Masonry-Timber Building}

The traditional masonry-timber structure comprises vertical-bearing elements, such as walls and columns, made of masonry, while timber is used to transfer forces horizontally on structural elements, such as beams and slabs. This type of structure was the main building type before modern Western concrete was introduced to China. The main difference between Western and local traditional Chinese traditional timber structures is in their verticalbearing elements; i.e., the former uses a masonry wall while the latter uses timber columns. The walls in the Western buildings are structural elements as well as envelopes, while in most cases, the walls in the Chinese buildings are only envelopes.

The earliest masonry-timber structures after the introduction of Western culture into China show obvious characteristics of transplantation of building techniques. Because of the lack of local professionals experienced in Western building techniques, a large number of traditional Chinese craftsmanship techniques and materials were used in the construction of details in the earliest buildings on the Bund. In this way, Chinese craftsmen used their traditional Chinese structures and native materials to imitate the Western-style architecture described by their foreigner clients. This was the beginning of the importation of Western architectural styles into Shanghai as unique features of these early masonry-timber structures.

From 1858, Shanghai began to produce European-style red bricks. The famous Bailianjing machine-made brick and tile factory was established in 1879. The appearance of manufacturing industries for these Western architectural materials in Shanghai promoted the development of masonry-timber structures. The British architect, Geo Strachan, arrived in Shanghai in 1850 and founded Geo Strachan Co., which was the first architectural design company in Shanghai (Delande 1998). These events were also the impetus for the maturing masonry-timber construction industry in Shanghai. From its architectural design to materials, the Western masonry-timber structure system was transferred incrementally from an acclimatised colonial type in the early period to the later classical Western style.

\section{North Bandinel \& Co. Building (No. 17-19 Fuzhou Road)}

The oldest existing building on the Bund is the North Bandinel \& Co. Building located at 17-19 Fuzhou Road, which is considered to have been built from 1855 to 1857 (Chen 2007). The building is a stone-brick-timber-structured building in the colonial veranda-style, which comprises two stories with a hip roof of grey-green tile (Figure 2). The ground floor windows use semicircle arches while the first-floor windows use pointed arches. The plane of the building's wall looks like the Chinese character ' 回' and there are six arches in the north-south direction, which is $22.4 \mathrm{~m}$-long, as well as 11 arches in the east-west direction, which is $40.4-\mathrm{m}$ long. Each corner of the first floor has a cantilever balcony. The internal brick walls are 17.5-in thick and the roof truss uses a triangular timber truss system. The external stone masonry walls are decorated with exposed granite. This method differed from the popular method of that period, when walls were rendered with mortar; therefore, this building may have been the only one of its type (Qian 2005). The homogeneous façade with pointed arches demonstrate a certain colonial style and its unique stone exterior walls show that the old hybrid masonry-timber structure of modern Shanghai architecture still had not been developed fully. 


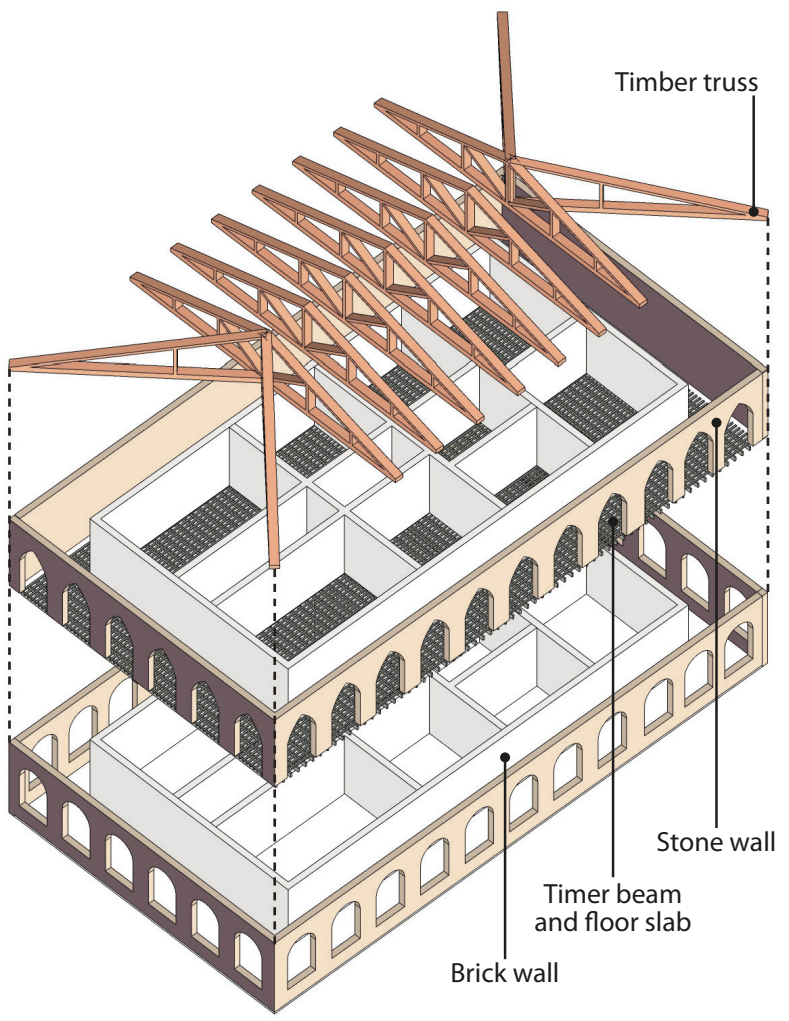

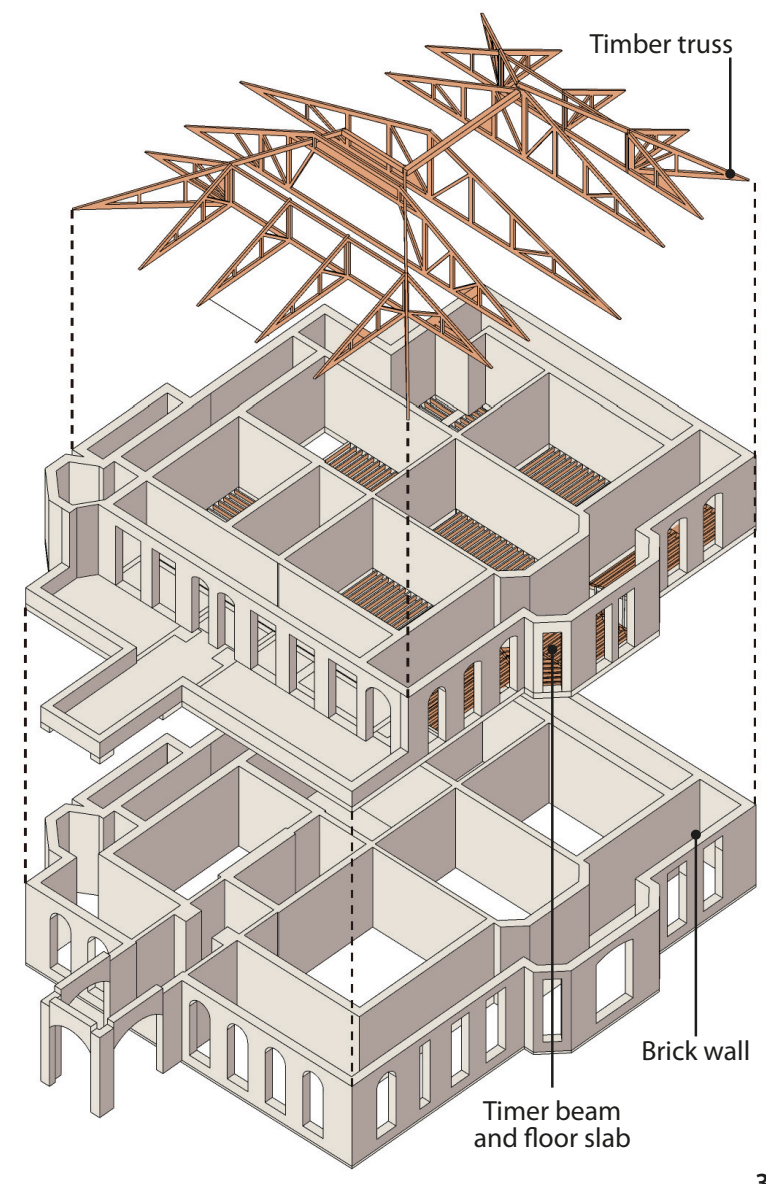

Figure 2 Structural Model of the 17-19 Fuzhou Road (Source: the author).

Figure 3 Structural Model of the British Consulate-General (Source: the author).

\section{Former British Consulate House (No. 33 East Zhongshan Road)}

The former British Consulate House was located at No. 2 house in No. 33 Zhongshan Road and used as the residence of the British Consulate General. Construction took two years until completion in 1884. The brick-timber structure house was built in the Victorian Romanesque architectural style in two stories with a sloped roof of grey-green tiles. The plane of the building's wall is nearly rectangular. Verandas are on the eastern and southern sides of the ground floor, with a veranda and terrace on the southern side of the first floor. The ground floor windows use arches while the firstfloor windows use flat arches. There are seven arches on the southern and eastern sides, which are 24-m and 34-m long, respectively. The black-brick external walls are not plastered, and some cornices and arches are made of red bricks (Zhang 2011). The roof truss uses the triangular timber truss system (Figure 3, Figure 4). Compared with the North Bandinel \& Co. Building, the former British Consulate House presents a more authentic European continental architectural style and the hybrid masonry-timber structure is more mature.

\section{Phase 2: New Hybrid Structure: Masonry-Steel- reinforced Concrete Building}

In 1868, reinforced concrete was invented by Joseph Monier, a French gardener, who used Portland cement. In 1872, the world's first reinforced-concrete building was completed in New York. Meanwhile, modern Shanghai architecture still mainly used the old hybrid masonrytimber structures. However, new materials such as cement, concrete and steel were introduced along with the increasing numbers of foreigners coming to Shanghai. Reinforced concrete has a better bend capacity than timber; therefore, it was possible to replace timber with reinforced concrete as the main structural material to expand space and transfer forces horizontally. Imported cement and concrete were used for the first time in the construction of the British Shanghai Yangshupu Waterworks, which was completed in 1883. Shanghai's first concrete product factory went into operation seven years later. The Shanghai Municipal Council's (SMC) first building codes for concrete proportions were set in its Rules for Foreign Buildings (1903). The 

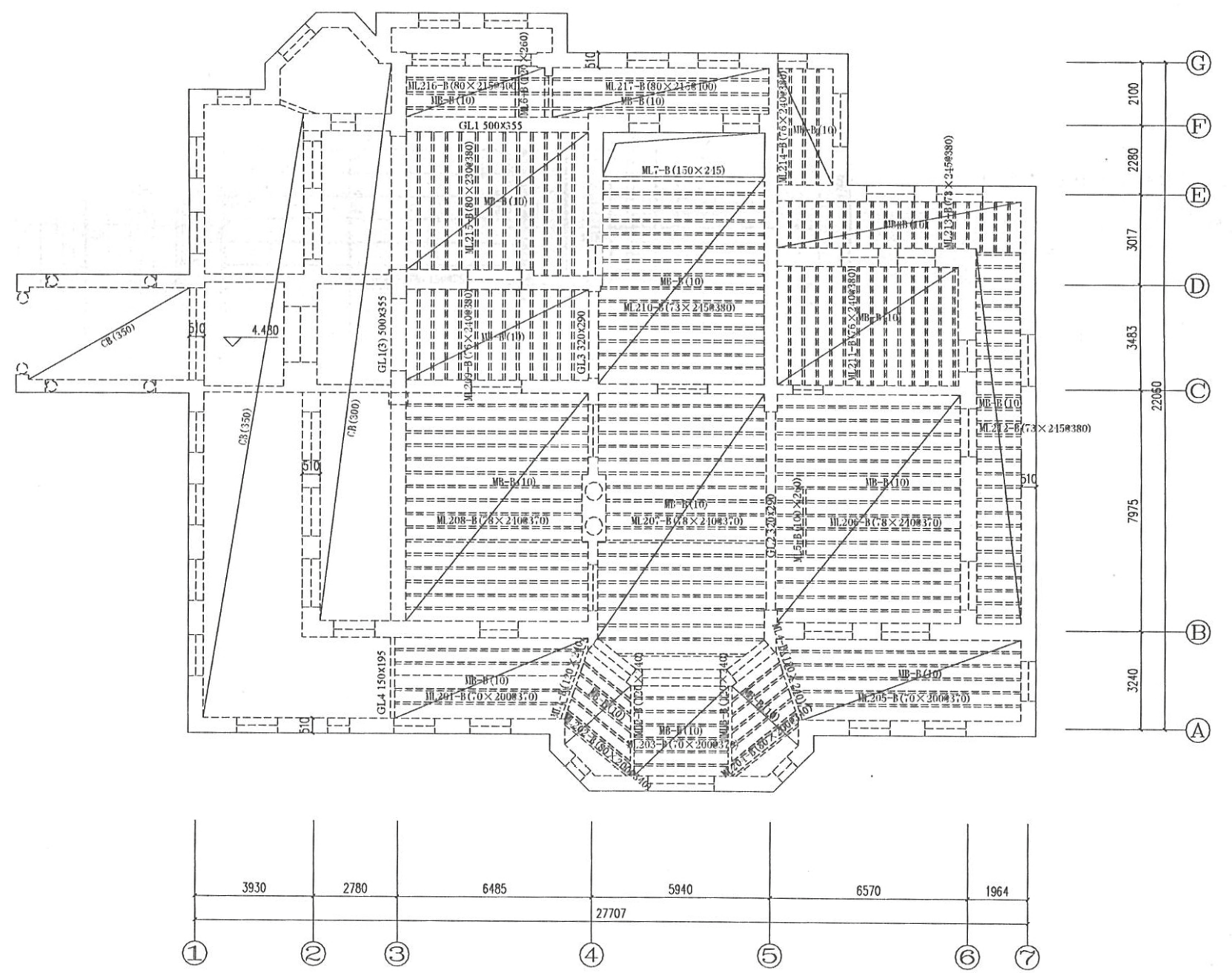

Figure 4 Second floor structural plan of the former British Consulate House (Source: the author).

introduction of concrete into China completed the process of importation of building techniques to homemade construction, from industrial to civil architecture, and from unordered to legally controlled construction.

The primary characteristic of the new hybrid masonrysteel-reinforced concrete structures was the continuance of the old hybrid structure; therefore, brick walls still transferred load vertically, while steel-reinforced concrete or steel structures transferred load horizontally instead of timber beams or floor slabs. From a structural perspective, this type of structure is in a transition period between the old hybrid structures and uniform structures. The properties of the new materials were not given full play yet, but their introduction increased the span and bearing load of new buildings. With these new techniques, building heights rose from two or three stories to six stories because of the materials' greatly improved ability to resist horizontal loads.
The China Merchants Steam Navigation Company Building (No. 9 East Zhongshan Road)

In 1901, the China Merchants Steam Navigation Company Building was constructed where Bandinel \& Co. originally had their garden. The building was designed by Gabriel James Morrison Co. and contracted by Daoren Zhao. It was built using local materials and a construction team from Hong Kong. At that time, T. H. Harris was the general manager of Navigation Company, and his influence led to the northern American colonial style used in the building's architecture (Qian 2005). The building is three stories high and is constructed with a sloped roof using bricks, timbers, steels and reinforced concrete. The external walls on the ground floor use stone masonry, while other walls use red-brick masonry without plastering. All ground floor walls were built up using composite mortar while other walls were built up using lime mortar. Eight 

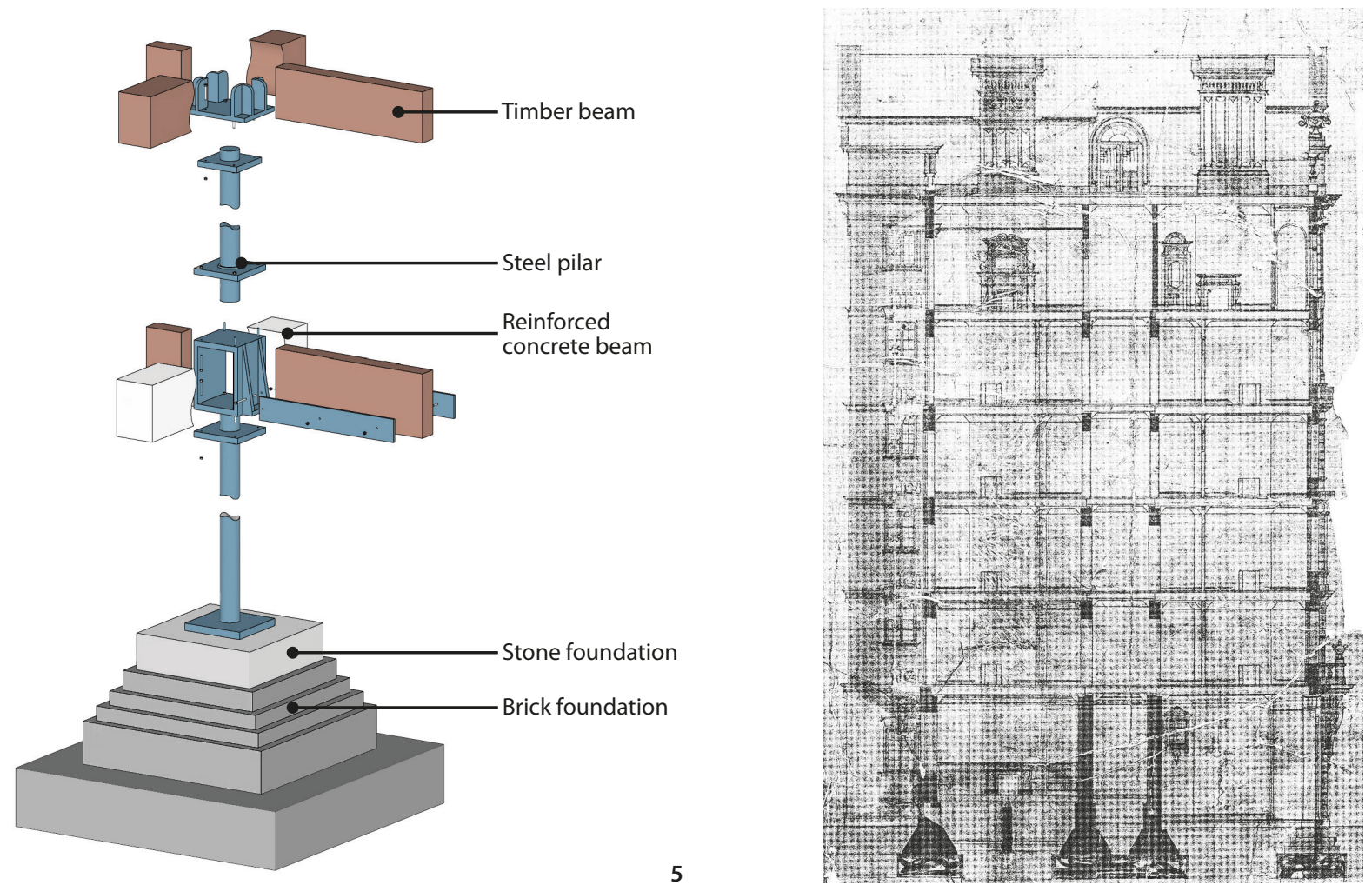

Figure 5 Steel column joints with timber and concrete beams of the China Merchants Steam Navigation Company Building (Source: the author). Figure 6 The section of the Palace Hotel (Source: Shanghai Urban Construction Archive).

round steel columns with a $127-\mathrm{mm}$ diameter were set in the interior. The most interesting aspect of the building's construction was that the north-south beams were reinforced concrete while the east-west beams were wood. A prototype frame structure using a $3,880 \mathrm{~mm} \times 3,620 \mathrm{~mm}$ grid was made using three kinds of materials: one traditional and two new (Figure 5).

\section{Phase 3: A New System: Reinforced Concrete or Steel Frame Buildings}

Around 1910, frame structures were introduced to China and generally applied to public buildings in Shanghai's foreign settlements. The frame structure building system makes high-rise buildings possible, which is also an important symbol of Shanghai's modern era. Due to their frame structure, the practice of using mixed structural elements based on different materials for different building purposes was able to be ended. These structures also made the most of the materials' properties for better structural integrity as well as resistance to earthquakes and uneven settling.

The Shanghai Telephone Company Building, first entirely reinforced-concrete-framed building built in Shanghai, was completed in 1908, only five years after the Ingalls Building, first reinforced-concrete-framed building in the world of its kind, was built in Cincinnati. Hence, Western building technologies were introduced extremely rapidly in China. This construction also showed the clear communication of technologies between Shanghai and the West as well as Shanghai's technology application capabilities.

Compared with the old and new hybrid building structures, reinforced-concrete frame structures allow larger spans and because their foundations are more stable, it has more potential for high-rise buildings. The speed of application of this building style in Shanghai was quite fast because many buildings adopted reinforced-concrete structures and foundations when the Bund was largely reconstructed for the third time in the 1920s and 1930s. The overall height of Bund buildings became more than six stories. Since then, a new structural era opened with the construction of modern Shanghai skyscrapers.

\section{The Former Palace Hotel}

The former Palace Hotel on the Bund was built in 1906 as a brick masonry-wood structure, but in 1926, a reinforced-concrete one-way inner frame structure was introduced to support reinforced-concrete beams on the existing brick masonry walls. In its budding state, this new structural form shows the transformation of the structural 

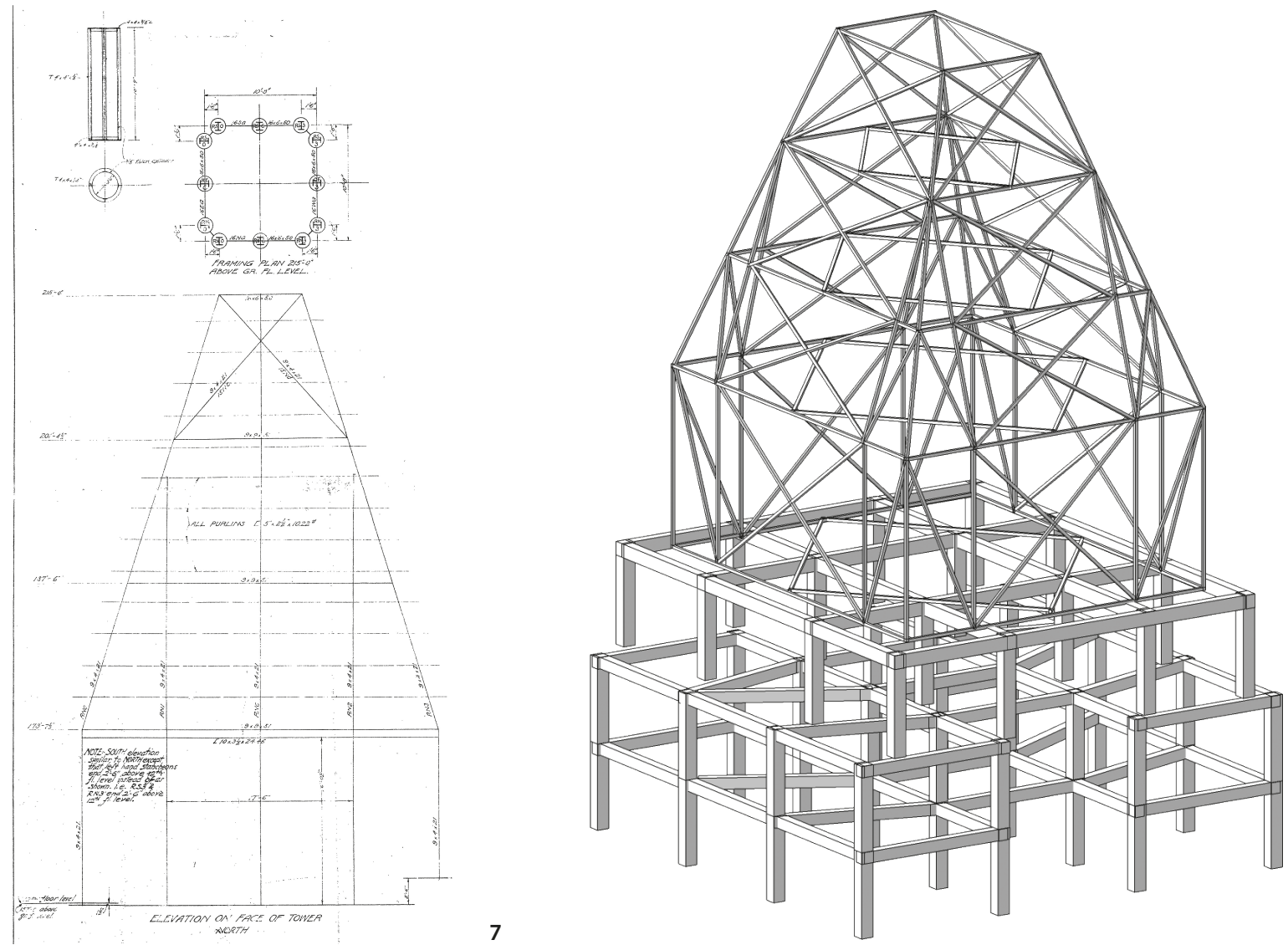

Figure 7 Structural Drawing of the Roof of the Sassoon House (Source: Shanghai Urban Construction Archive). Figure 8 The Sassoon House Spire with Complex Spatial Steel Structures (Source: the author).

system from mixed masonry-wood structures to frame structures (Figure 6).

In 1884, William Le Baron Jenney invented the steel frame structure system. The high strength and stiffness of steel make it possible to build taller buildings with longer spans. Based on the properties of iron, a steel frame and long-span steel structure system was developed and gradually replaced the original iron frame structures. Largespan steel structures are mainly used in special buildings such as factories, gymnasiums and theatres, while steel frame structures are more frequently used in civil buildings. Most of the first steel products were used in bridges and other industrial structures. In 1882, the Shanghai Electric Company built a workshop using a steel frame structure. In 1908, Shanghai's first all-steel structure, the Garden Bridge, was opened to traffic. In 1913, the first boiler workshop was built in Shanghai's Yangshupu Power Plant. This workshop was the first large-scale steel structure workshop built in Shanghai.

32 years after the first building with a steel frame structure was constructed in Chicago, in 1916, Palmer \& Turner Group's first work in Shanghai, the Dodwell \& Co. Building, took the lead in using steel frame structures in Shanghai. This indicates that steel structures became the main structure applied to multi-story and high-rise civil buildings in Shanghai, which has raised the height of modern Shanghai buildings from six or seven stories to more than 10 or 20 stories. This greatly changed modern Shanghai's skyline.

Steel structures were also used for roofs with irregular shapes and unsatisfactory traditional Chinese structural forms, such as the vault of the HSBC Bank Building and the spire of Sassoon House. The vault at the top of the HSBC Bank Building and the Sassoon House spire are complex spatial structures with good structural integrity. An oblique parallel chord steel truss is also used on the top of the steel-framed octagonal pavilion on the ground floor of the Sassoon House, where the I-shaped steel members are anchored by bolts and iron sheets (Figure 7, Figure 8).

The Rules for Foreign Buildings (SMC 1903) obviously could not be adapted to the popularisation of frame structures. In 1916, the Shanghai Municipal Council issued the Rules with Respect to Reinforced Concrete and the Rules with Respect to Structural Steel separately to limit irregular designs and construction. 

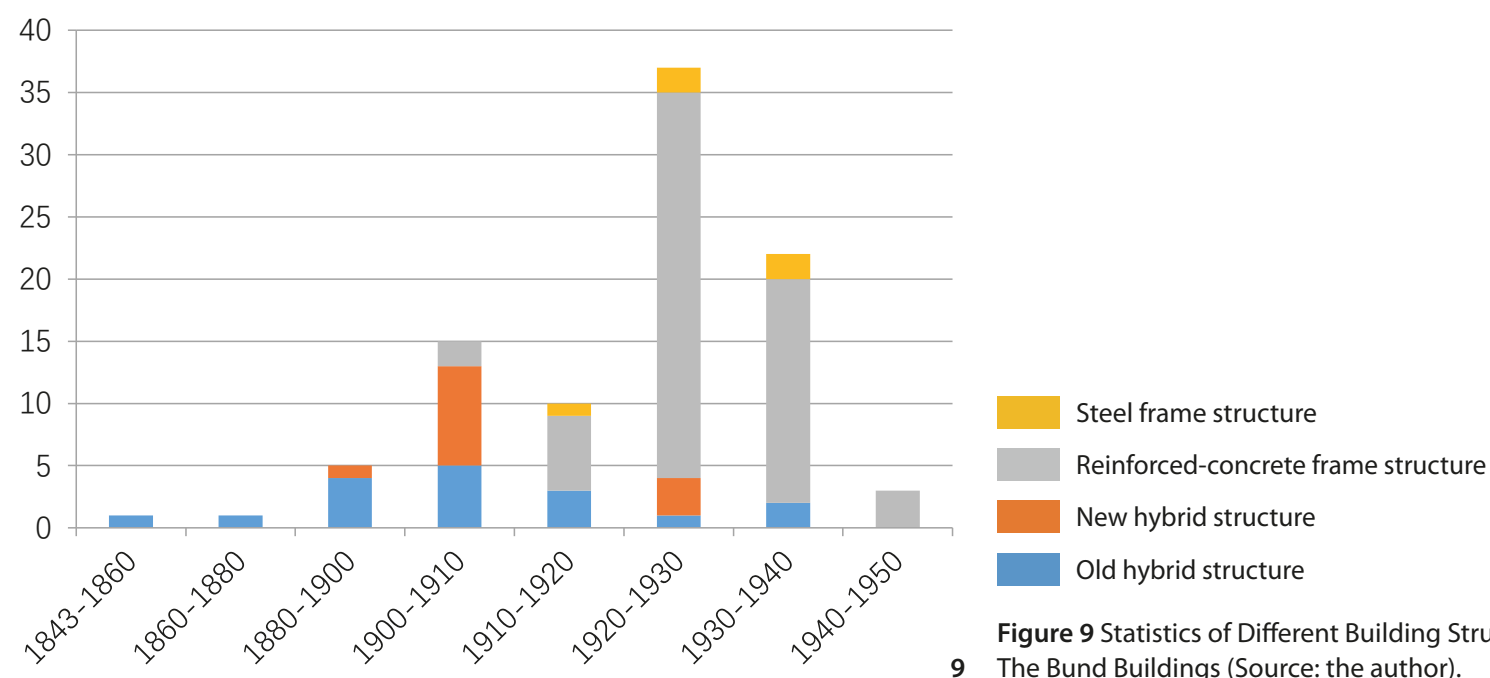

Figure 9 Statistics of Different Building Structures Used in 9 The Bund Buildings (Source: the author).

\section{Mechanisms and Motivations of the Structural Evolution}

The period of construction for the 89 Bund buildings concerned in this paper spans nearly 100 years of the British/ International Settlement. In terms of their overall distribution, only a few existing buildings were constructed in the $19^{\text {th }}$ century. The majority of buildings were constructed between 1920 and 1940, with only three completed after 1940. Among these 89 research objects, the buildings built during the $19^{\text {th }}$ century mainly consist of the old hybrid masonry-timber structures. A unique building among the $19^{\text {th }}$-century buildings is the innovative British Merchant Water Company Building at 464-466 Middle Jiangxi Road, which was an early adopter of the new hybrid structure by applying new materials. From 1900 to 1910, the new hybrid structures and the old hybrid masonrytimber structures were almost equally divided in new buildings and reinforced-concrete structures appeared for the first time. The Shanghai Club (No. 2 East Zhongshan Road) and the China Mutual Life Insurance Co. Building (No. 93 Guangdong Road), which were both completed in 1910, are the only two examples of reinforced-concrete frame structures built before 1910. After 1910, reinforcedconcrete structures were the main building type and construction peaked in 1920-1930. During this decade, more than 30 buildings adopted this new structural form, which shows its popularity in this period. However, even after the maturation and popularity of the frame structure system, the previous structural types, including the old and new hybrid structures, did not immediately withdraw from the historical stage, but continued to be used in low-rise residential buildings among other types. On the one hand, this shows that these structural types have become a part of Shanghai's architectural culture with comparable continuity to technological progress in the region. On the other hand, this could reflect that there are no higher requirements for structural integrity at the level of building and structural regulations because of the emergence of new technologies (Figure 9).

\section{Partly Improved to Systematic Renovation: The Pivotal Role Played by Progress in Material Tech- nologies}

Progress in architectural material technologies is one of the key factors for structural evolution. During periods with poor communication, the extensive transportation of architectural materials was impractical because of its high cost. In most cases, regional materials could be used in regional building structures and styles. In contrast to its non-structural role in traditional Chinese architecture, masonry walls act as the main vertical structure component in Western masonry-timber structure systems. Horizontal structure types could then be developed, such as arches and vaults. Black bricks were used in China for a long time and were also popularly used in modern Shanghai architecture in the first few years after the port opened to foreigners. However, European red bricks were produced in Shanghai since 1858 and they replaced the major role that grey bricks previously played in masonry-timber structures.

The North Bandinel \& Co. building was constructed between 1855 and 1857. Its construction adopted stone masonry walls without plastering. European red bricks were not yet being manufactured in Shanghai at this time. The owner possibly did not trust the locally produced 
black bricks because they chose to use natural granite from Guangdong, which was also generally used in Europe (Zheng 1999). However, black bricks were used in the construction of both former British Consulate Houses, which were built in 1873 and 1884, respectively.

The first appearance of concrete in Shanghai was during the construction of the Shanghai Yangshupu Waterworks in 1883, while the first cement factories in China were the Tangshan and Macao Qingzhou Qingying cement factories built in 1886. In 1915, cast-in-place concrete floor slabs came into use following the introduction of concrete mixers to Shanghai. The rapid increase in buildings using reinforced-concrete frame structures after 1910 was also related to the introduction of concrete mixers. Construction of Shanghai Yangshupu Power Station, which was Shanghai's earliest mega steel structural system factory, was completed in 1913.

The China Merchants Steam Navigation Company Building, which was built in 1901, is a very important example of structural evolution. On the one hand, considering its building volume and scale of interior spaces, its architecture is almost the same as the masonry-timber buildings of the same period. Its external walls also use red brick masonry without plastering. On the other hand, new materials were used imperceptibly in the structure. For example, the ground-floor masonry walls differ from the other plain brick walls because composite mortar with cement was used in their masonry. Eight round steel pillars with a $127-\mathrm{mm}$ diameter acted as the building's interior structure instead of brickworks or brick columns. Reinforced-concrete beams were used in the north-south direction while timber beams were used in the east-west direction. New materials, such as reinforced concrete, steel and composite mortar, appeared in a building that looked like a masonry-timber structure because of its partially improved method of construction.

The Yangtze Insurance Building was built 17 years after the China Merchants Steam Navigation Company Building using a reinforced-concrete frame structure instead of the hybrid masonry-timber structure. This structural system was much more uniform because of its use of simplex materials; thus, the building was constructed to become around $30 \mathrm{~m}$ tall. During this period, reinforcedconcrete frame structures were predominant. The evolution of these building structure systems, i.e., the replacement of masonry-timber structures with new materials, such as steel, reinforced concrete and cement, changed from a partial improvement to a systematic innovation of construction systems.

\section{Changes from Control Based on Experience to Rational Restrictions}

As a traditional hybrid structural system, the value of masonry-timber structures is in their ability to deal with different structural needs using the different features of brick and timber materials. For example, brick masonry is good for transferring loads vertically while timber is good for weight-bearing or bending moments and transferring loads horizontally. However, this kind of weight division can also cause some concerns because brickworks have difficulty resisting bending and horizontal loads. Therefore, reinforced concrete replaced timbers. Nowadays, ring beams, plaster facing and load-bearing columns are now attached to brick walls to satisfy the building regulations for seismic movement when masonry-timber structure buildings are renovated. In addition to the hybrid structure system, the bonding strength of different materials is so closely related to construction methods and quality that it is difficult to rely on structural calculations but instead control the construction only by experience. From a structural perspective, the Shanghai Municipal Council (1900) limited the maximum building height to two stories in its Rules for Chinese Buildings (cited in Shi 2001). However, surveyors had greater authority to determine the maximum height for some buildings of special types using their own experience. Although some relevant structural requirements, such as wall thickness, materials, lap joints, masonry method, open holes and beam support were regulated in the Rules for Foreign Buildings (SMC 1903), these rules still depended on the practical control of the surveyors' experience, but not quantitative indices such as the intensity index of materials and structural calculation parameters.

Between 1914 and 1916, Shanghai Municipal Council began to accept and think highly of new architectural types and methods for building new structures as well as materials technology. Furthermore, the Shanghai Municipal Council tried to preferably control the types of buildings by regulating and quantifying these architectural types and building methods (Tang 2009). The Rules with Respect to Reinforced Concrete and the Rules with Respect to Structural Steel were issued in the same year as the New Proposed Rules for Foreign Buildings (1917) (cited in Chen, 1933). Among them, the Rules with Respect to Reinforced Concrete (1917) stipulates some detailed information, such as bending moment parameters, standard pressure limits for the diameter and thickness of beams as well as basements, and the bearing demand for columns and walls. Testing methods in construction and quality standards 
for work were also stipulated in particular. These were the first expert regulations for architectural structures in Shanghai; thus, they confirmed the primary status of frame structures in new buildings. Other than fixed data and scales, calculation formulas for steel structures were also presented. This meant that Shanghai architectural designs changed from depending on prior experience to depending on scientific calculations. However, it is very important to note that no structural system concepts or influence of wind load were considered in the regulations, although more control of structural components was included. The Rules for Building Foundation, Walls, Reinforced Concrete and Steel Structure (SMC 1936) issued 20 years later provided more content about managing wind load were included, but structural system concepts were still undetermined.

\section{Transplantation to Adaptive Localisation}

Western structural technologies in Shanghai underwent a process of transplantation to adaptative localisation. Using building foundations as an example, the principal problem for modern Shanghai buildings is the underlying soil. Shanghai is located on the Yangtze River Delta, which has been piled up by sediment. The deposit layer thickness in Huangpu Park on the Bund is almost $300 \mathrm{~m}$. Although brick foundations, which can be used on European soil environments, could meet the load-bearing requirements in Shanghai, the serious issue of soil settlement was still present. All architectural design companies attempted to use innovations in foundational building technologies because of this problem. A variety of foundations were used in the Bund buildings mentioned above. The former British Consulate House used a strip foundation under walls made from bricks and stones. The China Merchants Steam Navigation Company Building used a rigid masonry strip foundation and independent foundation with a $400 \mathrm{~mm}$-thick trinity mixture fill cushion layer under them. The Yangtze Insurance Building (1917) used a stiffened raft foundation, with foundation beams arranged on the bottom plate along a point-axis-net. Soil settlement occurred unevenly at different levels beneath these three buildings. Because of its 30-m height, the north-south gradient of the Yangtze Insurance Building reached 14.9\%o and continues increasing. Thus, the transplanted Western structural foundation technology during the early period was not well adapted to the circumstances of the Shanghai soil matrix. This contradiction became more prominent after the appearance of reinforced-concrete frame structures and the related substantial increase in building heights. In 1916, by piling timbers into the foundation and then laying a concrete pad on top of them, John Richie, a partner at the Palmer \& Turner Group, successfully considered the characteristics of Shanghai soil in constructing the McBain Building (Delande 1998). Since then, a structural approach to Shanghai's soft soil matrix was identified. 10 years later, the Bank of East Asia Building, which was built in 1926, adopted a stiffened raft and concrete pile foundation with 297 piles under its beam-andslab raft. Consequently, the biggest gradient of the Bank of East Asia Building is only 5.1\%o today, which shows that the Western technologies could deal with the special circumstances of Shanghai's soil matrix after a process of adaptive localisation.

This adaptive localisation of building structures was first expressed by the introduction of technologies, but the cultivation of technical personnel was more important. According to the population censuses done by the Shanghai Municipal Council in the Settlement between 1865 and 1875, there were only 83 engineers and machinists among 3,278 foreigners in 1865 and 4.6\% engineers among 1,666 foreigners in 1875. This shows that technical personnel were limited during the early years of the British Settlement and this is reflected in the combination of foreign technologies and local materials in the buildings of that time. After 1890, increasing numbers of foreign architects and engineers came to China. Natalie Delande's study (1998) found only five registered structural engineers in Shanghai in 1902, which increased to 10 and 15 in 1904 and 1909, respectively, and finally to 30 in 1912. The Chinese government established a registration system for architects in 1912, but did not recognise the status of structural engineers until 1932. Thus, the increased numbers of structural engineers in Shanghai enabled the localisation of foreign building technologies.

\section{Conclusion}

Through the analysis above, we can conclude that for a particular type of structure, a state of perfection could not be achieved from the beginning, but the imported technologies became more practical through continuous improvement to accommodate local conditions. A transplantation trend could be observed in the application of combinations of different materials and structural designs drawn from different cultural backgrounds in both old and new hybrid structures in the early period of the Settlement and the addition of new materials in the late $19^{\text {th }}$ century. Following this gradual increase in technological proficiency, the scientific nature and applicability of 
structures were improved to adapt successfully to the local conditions; thus, Western-style structures were finally localised in Shanghai.

The evolution of different structural types was a process of changing from partial improvement to overall innovation. On the one hand, the evolution of buildings was reflected in the layer-by-layer improvement of structural materials in masonry-timber structures. New materials such as concrete and steel were first used to replace wooden and masonry components and then were used to meet the specific requirements of the building site. On the other hand, the gradual improvement of structural systems by applying different materials for vertical and horizontal components into a more unified structural system using only reinforced-concrete and steel materials also reflects the evolution of modern Shanghai buildings.

\section{References}

Chen, Xi. 2007. “The Witness of the Early Interface Along the Bund-Architecture Research of the No.17-19 Fuzhou Rd. Building." Master diss. Tongji University.

Chen, Yanlin. 1933. Shanghai dichan daquan [A Complete Collection of Shanghai Real Estate]. Shanghai: Shanghai Real Easte Research Institute.

Delande, Natalie. 1998. “The Fundamental Role of Technological Culture in the Chinese Modern Architecture History." In Proceedings of the 5th Symposium on Chinese Modern Architectural History, 96-106.

Li, Haiqing. 2004. Zhongguo jianzhu xiandai zhuanxing [The Modern Transformation of Chinese Architecture]. Nanjing: Southeast University Press.

Qian, Zonghao. 2005. Bainian huiwang: Shanghai Waitan jianzhu yu jingguan de lishi bianqian [The History and Evolution of the Architecture and Landscape of the Bund in 100 years]. Shanghai: Shanghai Science and Technology Press.

Shi, Meiding. 2001. Shanghai zujie zhi [Shanghai Concession Records]. Shanghai: Shanghai Academy of Social Science Publishing House.

SMC (Shanghai Municipal Council). 1903. Rules for Foreign Buildings. Shanghai Archives. File U1-2-246.

SMC (Shanghai Municipal Council). 1936. Rules for Building Foundation, Walls, Reinforced Concrete and Steel Structure. Shanghai Archives. File U1-14-6085.

Tang, Fang. 2009. Dushi jianzhu kongzhi: jindai Shanghai gonggong zujie jianzhu fagui yanjiu [The Urban Architectural Control: Research on the Building Codes of the International Settlement of Modern Shanghai].
Nanjing: Southeast University Press.

Zhang, W. 2011. "Structural Investigation Report of No.2 Bund 33 of Shanghai." Unpublished report.

Zheng, Shiling. 1999. Shanghai jindai jianzhu fengge [The Evolution of Shanghai Architecture in Modern Times]. Shanghai: Shanghai Education Press. 